\title{
ARTIMIZIA EXTRACT AS GROWTH PROMOTORES AND INCREASED OREOCHROMIS NILOTICUS (L.) RESISTANT AGAINST A. Hydrophilia
}

\author{
Soliman H.G. ${ }^{1}$, El-Gamal R.M.A. ${ }^{2}$, Ali A.A. ${ }^{3}$
}

1- Potany and microbiology dep. Fac. Of science azhar univ.

2- Fish health dep. Center lab. Of aquaculture resaerch ARC.

3- Abo- Humad hospital health minsetery.

\begin{abstract}
The main objective of this study was the use of (Artimizia) extract as immunostimulant effect, growth promoters and fish resistance to Aeromonas hydrophila infection; in Nile tilapia, Oreochromis nilocticus fingerlings. Four monosex fish (12 \pm 2 gram $)$ groups fed commercial diets (30\% crude protein) and isocaloric (4.4 $\mathrm{kcal} / \mathrm{gm}$ ) contained 0.0 (control) and $0.5,1$, and $1.5 \%$ of Artimizia extract. All diets are isonitrogenous. The result showed that Diet containing $0.5 \%$ Artimizia extract significantly $(\mathrm{p}<0.05)$ gave the better growth performance as reflected in weight gain \%, Specific Growth Rate (SGR), Feed Conversion Ratio (FCR), Feed Efficiency Ratio (FER), Protein Efficiency Ratio (PER), Apparent Protein Utilization (APU) and Energy Utilization (EU). Also the survival rate was enhanced. Artimizia extract supplemented diet had no effect on body composition of $O$. nilotiticus. (Artimizia) extract supplement diet improved fish health, which improved Hemoglobin $(\mathrm{Hb})$, Red Blood Cells (RBCs), hematocrit $(\mathrm{PCV})$, total protein, albumin and globulin while showed a decrease in creatinine, urea, Aspartate aminotransferase (AST), Alanine aminotransferase (ALT) and glucose in all treatment groups. Artimizia extract supplement diet had Positive effect on $\mathrm{Hb}$, RBCS, PCV, total Protein, albumin, globulin, creatinin, glucose, urea, AST and ALT.
\end{abstract}

\section{Introduction}

The Nile tilapia has distinctive, regular, vertical stripes extending as far down the body as the bottom edge of the caudal fin, with 
variable coloration. Adults reach up to $60 \mathrm{~cm}$ (24 in) in length and up to $4.3 \mathrm{~kg}(9.5 \mathrm{lb})$, It lives for up to nine years. (Froese and pauly 2015) It tolerates brackish water and survives temperatures between 8 and $42{ }^{\circ} \mathrm{C}$ (46 and $108^{\circ} \mathrm{F}$ ). (Froese and pauly 2015) It is an omnivore, feeding on plankton as well as on higher plants. Introduced tilapia can easily become an invasive species (see Tilapia as exotic species). It is a species of high economic value and is widely introduced outside its natural range; probably next to the Mozambique tilapia (O. mossambicus). Feed additives are important to improve feed utilization and animal performance, herbs and spices have been added to different types of food to impart flavor as well as to improve storage stability. Many herbs and spices have been shown to impart antioxidant effects in food; the active principles are phenolic(Tanabe et al., 2002).

A wide variety of phenolic substances derived from herbs and spices possess potent anti-inflammatory, anti-mutagenic, anticarcinogenic and anti-tumour activities, which contribute to their chemopreventive potential (Surh, 2002).

Ibrahim et al., 1998 showed successful use of spices and natural herbs in fish nutrition including marjoram, basil, licorice roots, black seeds, peppermint, fenugreek seeds and caraway seeds, and also ElSaidy (1999) reported that the dried onion meal can be used in diet in Nile tilapia but in our study, we showed that Artimizia extracts are used as diets.

Artemizia herba-alba is a short shrub usually found in Northern Africa and the Middle East. and are used as medicine. People take Artemisia herba-alba for cough, stomach and intestinal upset, the common cold, measles, diabetes, yellowed skin (jaundice), anxiety, irregular heartbeat, and muscle weakness. It is also used for parasitic infections such as roundworms, pinworms, tapeworms, hookworms, and flukes. Some chemicals contained in Artemisia herba-alba seem to kill parasites and bacteria. Some other chemicals might lower blood sugar.

Marjoram plants Origanum marjorana H. Or Marjorana hortensis L. Or Origanum vulgare are considered as an importnat medicinal crop in Egypt with high production and great applications. (Papageorgrou et al., 2003) activities, mainly because of its high 
content of phenolic acids and flavonoids, which is useful in health supplements and food preservation (Vagi et al., 2005). Traditionally, the plant has been used as a folk remedy against asthma, indigestion, headache and rheumatism (Jun et al., 2001).

The main objective of this study was to study the effect of difeernt levels of Artimizia supplemented to the diets as natural growth promoter on growth performance, feed utilization, body composition, immunological blood parameters, entropathogenic Aeromonas hydrophila challenge of all male Nile tilapia Oreochromis niloticus L. fingerlings.

\section{Materials and Methods}

The present study was carried out at Central Laboratory for Aquaculture Research, Abbassa, Abou-Hammad, Sharkia, Egypt, during the year 2013 in order to determine the responses of tilapia fingerlings to Artimizia extract as feed additive.

\section{Feed preparation:}

\section{Extraction of Artimizia:}

five hundred (500) gm of air dried leaves of Artimizia was subjected to exhaustive extraction with ethyl alcohol (95\%) using soxhlet apparatus until complete extraction. Each of the obtained extract was the cooled filtered and evaporated under vacuum for concentration which was dissolved in Dimethylsulfoxide (DMSO). The solution was mixed with petroleum ether $\left(\mathrm{BP}, 40-60^{\circ} \mathrm{C}\right)$, and centrifuged at $5000 \mathrm{rpm}$.( Christen and Veuthey, 2001)

\section{Feed preparation:}

Diets were formulated isonitrogenous (30\% crude protein and $7 \%$ lipid). Dietary formulation and proximate analysis of the experimental diets are shown in table (1). Experimental diets were formulated to meet the nutritional requirement of fish (NRC, 1994). the diet was divided into four parts, first one (control) free from Artimizia extract. other parts contained $0.5,1,1.5 \%$ Artimizia extract. Dry ingredients including artimizia were mixed homogeneously and $100 \mathrm{ml}$ of water was added per $\mathrm{kg}$ diet and the mixture were blended. Pelleting of each diet was carried out by passing the blended mixture through 
laboratory pellet machine with a $(1 \mathrm{~mm})$ diameter matrix. The diets were prepared palletized.

Table (1): Ingredients and chemical analysis of the experimental diets (on dry matter basis) containing different levels of Artimizia extract.

\begin{tabular}{lllll}
\hline & $\begin{array}{c}\text { Control } \\
\mathbf{0 \%}\end{array}$ & $\mathbf{0 . 5 \%}$ & $\mathbf{1 \%}$ & $\mathbf{1 . 5 \%}$ \\
\hline Ingredients & & & & \\
Fish meal & 9.1 & 9.1 & 9.1 & 9.1 \\
Soybean meal & 45.5 & 45.5 & 45.5 & 45.5 \\
Ground corn & 15.31 & 15.31 & 15.31 & 15.31 \\
Wheat bran & 19.21 & 19.21 & 19.21 & 19.21 \\
Starch & 4 & 3.5 & 3 & 2.5 \\
Artimizia & $\mathbf{0}$ & $\mathbf{0 . 5}$ & $\mathbf{1}$ & $\mathbf{1 . 5}$ \\
Cod fish oil & 2.23 & 2.23 & 2.23 & 2.23 \\
Corn oil & 1.65 & 1.65 & 1.65 & 1.65 \\
Vitamins premix & 1 & 1 & 1 & 1 \\
Minerals premix & 2 & 2 & 2 & 2 \\
Total & 100 & 100 & 100 & 100 \\
\hline Chemical analysis \% & & & & \\
\hline Dry matter & 91.68 & 91.63 & 91.51 & 91.44 \\
Crude protein & 30.11 & 30.36 & 30.41 & 30.41 \\
Crude fat & 7.11 & 7.18 & 7.31 & 7.42 \\
Ash & 8.13 & 8.03 & 8.17 & 8.32 \\
Fiber & 5.45 & 5.52 & 5.25 & 5.33 \\
NFE & 49.2 & 48.91 & 48.86 & 48.52 \\
GE (Kcal/100 gm) & 4390.3 & 4399.1 & 4412.3 & 4408.7 \\
P/E ratio & 68.58 & 69.01 & 68.91 & 68.98 \\
\hline
\end{tabular}

1-Vitamin premix (per kg of premix): Thiamine, $2.5 \mathrm{gm}$; riboflavin, $2.5 \mathrm{gm}$; pyridoxine, $2 \mathrm{gm}$; inositol, $100 \mathrm{gm}$; biotin, $0.3 \mathrm{gm}$; pantothenic acid, $100 \mathrm{gm}$; folic acid, 0.75 gm; para-aminobenzoic acid, $2.5 \mathrm{gm}$; choline, $200 \mathrm{gm}$; nicotinic acid, 10 gm; cyanocobalamine, $0.005 \mathrm{gm}$; a-tocopherol acetate, $20.1 \mathrm{gm}$; menadione, $2 \mathrm{gm}$; retinol palmitate, 100,000 IU; cholecalciferol, 500,000 IU (Jauncey and Rose, 1982).

2-Mineral premix (gm/kg of premix): $\mathrm{CaHPO}_{4} \cdot 2 \mathrm{H}_{2} \mathrm{O}, 727.2 ; \mathrm{MgCO}_{4} .7 \mathrm{H}_{2} \mathrm{O}$, 127.5; KCl, 50; $\mathrm{NaCl}, 60 ; \mathrm{FeC}_{6} \mathrm{H}_{5} \mathrm{O}_{7} .3 \mathrm{H}_{2} \mathrm{O}, 25 ; \mathrm{ZnCO}_{3}, 5.5 ; \mathrm{MnCl}_{2} .4 \mathrm{H}_{2} \mathrm{O}, 2.5$; $\mathrm{Cu}(\mathrm{OAc})_{2} \cdot \mathrm{H}_{2} \mathrm{O}, 0.785 ; \mathrm{CoCl}_{3} \cdot 6 \mathrm{H}_{2} \mathrm{O}, 0.477 ; \mathrm{CaIO}_{3} \cdot 6 \mathrm{H}_{2} \mathrm{O}, 0.295 ; \mathrm{CrCl}_{3} .6 \mathrm{H}_{2} \mathrm{O}, 0.128$; $\mathrm{AlCl}_{3} \cdot 6 \mathrm{H}_{2} \mathrm{O}, 0.54 ; \mathrm{Na}_{2} \mathrm{SeO}_{3}, 0.03$ (Jauncey and Rose, 1982).

3-Nitrogen-free extract $($ calculated by difference $)=100-($ Protein + Lipid + Ash + Fiber).

4-Gross Energy (GE) was calculated from NRC (1993) as 5.65, 9.45, and 4.1 $\mathrm{kcal} / \mathrm{gm}$ for protein, lipid, and carbohydrates, respectively. 


\section{feeding experiment:}

Nile tilapia fingerlings (monosex) of an average weight $12 \pm 2 \mathrm{gm}$. were collected from fish hatchery, Central Laboratory for Aquaculture Research, Abbassa, Abou-Hammad, Sharkia, Egypt. and placed in a fibrglass tank for 2 weeks for acclimatization to the laboratory condition. Acclimated fish were distributed randomly at a rate of 15 fish / $100 \mathrm{~L}$ aquaria. Each aquaria was supplied with compressed air via air-stones from air pumps. Settled fish wastes with one half of aquarium's water were siphoned daily and water volume was replaced by aerated tap water from the storage tank.

Diet was given to fish at a rate of $3 \%$ of live body weight twice daily at 9:00 and 13:00 hours Each diet was fed to triplicate aquaria of Nile tilapia for a period of 90 days. Fish in each aquarium were weighed biweekly and the amounts of feed were readjusted according to increase in body weight. The dead fish was daily recorded and removed. Also, each fish weight and length were measured. At the end of the experiments, fish were collected, counted, group weighed per treatments for growth performance as following:-

\section{- $\quad$ The total body weight gain (gm/fish):}

Total body weight gain $=\mathrm{Wt} 2-\mathrm{Wt} 1(\mathrm{gm} / \mathrm{fish})$

Where:

Wt 1: Mean initial body Weight (gm/fish)

Wt 2: Mean final body Weight (gm/fish)

- Weight gain \%:

$$
\mathrm{WG}=[(\mathrm{Wt} 2-\mathrm{Wt} 1) / \mathrm{Wt} 1] \times 100 \%
$$

Where:

Wt 1: Mean initial body Weight (gm/fish)

Wt 2: Mean final body Weight (gm/fish)

- $\quad$ Specific Growth Rate (SGR):

$\mathrm{SGR}=[(\operatorname{Ln} \mathrm{Wt} 2-\mathrm{Ln}$ Wt 1$) / \mathrm{T}] \times 100 \%$ 
Where:

Wt 1: Mean initial body Weight (gm/fish)

Wt 2: Mean final body Weight (gm/fish)

Ln: Natural Logarithm

- $\quad$ Feed Conversion Ratio (FCR):

$\mathrm{FCR}=$ Feed intake $/$ Body weight gain

- $\quad$ Feed Efficiency Ratio (FER):

$\mathrm{FER}=[$ Body weight gain $(\mathrm{gm}) /$ Feed intake $(\mathrm{gm})]$ x 100

- $\quad$ Apparent Protein Utilization (APU):

$\mathrm{APU}=\left[\left(\mathrm{P}_{2}-\mathrm{P}_{1}\right) / \mathrm{Pf}\right] \times 100$

Where:

$\mathbf{P}_{\mathbf{1}}$ : The protein content in fish at the start of the experiment (gm)

$\mathbf{P}_{2}$ : The protein content in fish at the end of the experiment (gm)

$\mathbf{P}_{3}$ : The protein intake (gm) during the experiment (on DM basis)

- $\quad$ Energy Utilization (EU):

$$
\mathrm{EU}=\left[\left(\mathrm{E}_{2}-\mathrm{E}_{1}\right) / \mathrm{Ef}\right] \mathrm{x} 100
$$

Where:

$\mathbf{E}_{1}$ : The energy content in fish at the start of the experiment

$\mathbf{E}_{\mathbf{2}}$ : The energy content in fish at the end of the experiment

$\mathbf{E}_{3}$ : The energy intake (Kcal GE) from

\section{Chemical analysis of fish:}

At the beginning of the experiment, fifteen fish were taken for the body composition analyses. At the end of experimenta, five fish from each treatment were taken to carry out the chemical analysis of the whole fish body. The test diets and fish samples were analyzed with 3-replicate sample according to the standard methods of AOAC (1990). 


\section{Analysis of the physico-chemical parameters of water:}

Water samples were collected biweekly from each aquarium. Water temperature, dissolved oxygen, $\mathrm{pH}$ degree also Unionized ammonia was measured (Boyd, 1990).

\section{Physiological measurement:}

\section{(1) blood samples:}

Fish were not fed in the 24 hours immediately prior to sampling. Fish were anaesthetized with buffered $\mathrm{MS}_{222}(50 \mathrm{mg} / \mathrm{L}$.) The collected blood was divided in two sets of eppendorf tubes. One set contained heparin, used as anticoagulant for hematological study (hemoglobin, hematocrit and red blood cell counting). The second set (without anticoagulant) was centrifuged at $5000 \mathrm{rpm}$ for 5 minutes at room temperature for serum collection and stored at $-20^{\circ} \mathrm{C}$ for further assays. After decapitation of fish samples of liver and muscle were taken and frozen for further biochemical analysis.(AST, ALT, total proteins, serum albumin, plasma glucose, urea and creatinine).

\section{Challenge test:}

At the end of expermint, the fish of each group were divided into two subgroups; the first subgroup was challenged I/P with pathogenic Aeromonas hydrophila $\left(0.3 \mathrm{ml}\right.$ of $\left.5 \times 10^{5} \mathrm{CFU}\right)$, A. hydrophila was obtained from Fish Disease Department, Central Labortory for Aquaculture Research. The second subgroup was injected I/P with 0.3 $\mathrm{ml}$ of saline solution as a control. Both subgroups kept under observation for 10 days to record the daily mortality rate as described by Schaperclacus et al., (1992). The recently dead and clinically diseased fish were subjected to bacterial re-isolation.

Efficiency of Artimizia extract for treatment of infected $O$. niloticus with $A$. hydrophilia:

O. niloticus were allotted into four equal groups. the first group was injected I/P with $\left(0.2 \mathrm{ml}\right.$ of $\left.5 \times 10^{5} \mathrm{CFU}\right)$ of $\boldsymbol{A}$. hydrophilia, the second group was injected I/P with $0.5 \mathrm{ml}$ of Artimizia extract, the third group was injected I/P with $0.2 \mathrm{ml}$ of A. hydrophilia and kept for 18 hours and treated by Artimizia extract once intraperitoneal at a dose of $10 \mathrm{mg} / \mathrm{kg}$ body weight (Mahady 2005). The fourth group was 
injected I/P with $0.2 \mathrm{ml}$ of saline as control. All groups were observed for 21 day post-infection.

\section{Statistical analysis:}

The obtained data statistically analyses were done using SPSS program version 10 (SPSS, Richmond, USA) as described by (Dytham 1999).

\section{Results and Discussion}

\section{Effect of Artimizia extract supplementation on physico-chemical} water quality parameters:

Analysis of water quality parameters revealed that water temperature ranged between 26 and $28^{\circ} \mathrm{C}$, dissolved oxygen concentrations ranged between 5.8 to $6.7 \mathrm{mg} / \mathrm{L}, \mathrm{pH} 7.4-8.1$ and unionized ammonia concentration range was $0.06-0.13 \mathrm{mg} / \mathrm{L}$. The chemical water analysis showed no apparent fluctuation during the experimental period; however, water quality was found to be within the acceptable range for tilapia growth this result agree with (Boyd, 1990).

\section{Effect of Artimizia extract supplementation on growth performance and survival rate of fish:}

Results in table (2) show growth performance of Nile tilapia. The highest average body weight, weight gain and weight gain \% (34.57, 22.4 and $167.6 \mathrm{gm} /$ fish respectively) were obtained at $0.5 \%$ Artimizia diet, whereas the control diet produced the lowest growth performance. The same trends were obtained in Specific Growth Rates (SGR) which increase significantly with different levels of Artimizia extract. The highest values $(1.51 \pm 0.05)$ were obtained with $0.5 \%$ Artimizia extract (1.51\%/day), while the lowest one was obtained with the control diet (1.29\%/day). Also, no significant differences in fish survival rate among different treatments $(p>0.05)$ and its range was $93.3-100 \%$. this result agree with Shalaby et al., (2003) who mentioned that Nile tilapia in aquaria for 70 days and fed on $36 \%$ crude protein diets supplemented with licorice roots at rate of $0,1,2,3$ and $4 \%$ from diet had positive effect on growth performance specially with $3 \%$ level, but in our study, when put Nile tilapia in aquaria for 90 days and fed with $30 \%$ crude protein diets 
Table (2): Growth performance (mean \pm SE) of Nile tilapia fed diets containing different levels of Artimizia extract after 90 days.

\begin{tabular}{ccccc}
\hline \multirow{2}{*}{ Items } & Control & \multicolumn{2}{c}{ Artimizia levels \% in the diets } \\
\cline { 2 - 5 } & & $\mathbf{0 . 5 \%}$ & $\mathbf{1 \%}$ & $\mathbf{1 . 5 \%}$ \\
\hline Initial weight (gm/fish) & $12.27 \pm 0.46$ & $12.17 \pm 0.15$ & $12.37 \pm 0.5$ & $12.23 \pm 0.36$ \\
Final weight (gm/fish) & $29.46^{\mathrm{c}} \pm 0.67$ & $34.57^{\mathrm{a}} \pm 0.85$ & $32.57^{\mathrm{ab}} \pm 0.55$ & $31.14^{\mathrm{b}} \pm 0.74$ \\
Weight gain (gm/fish) & $17.33^{\mathrm{c}} \pm 0.52$ & $22.4^{\mathrm{a}} \pm 0.97$ & $20.2^{\mathrm{ab}} \pm 0.33$ & $18.91 \pm 0.78^{\mathrm{b}}$ \\
Weight gain \% & $146.38^{\mathrm{bc}} \pm 7.03$ & $167.62^{\mathrm{a}} \pm 9.99$ & $155.21^{\mathrm{ab}} \pm 9.13$ & $149.61 \pm 6.02^{\mathrm{b}}$ \\
SGR (\% day) & $1.29^{\mathrm{c}} \pm 0.03$ & $1.51^{\mathrm{a}} \pm 0.05$ & $1.42^{\mathrm{ab}} \pm 0.05$ & $1.39 \pm 0.03^{\mathrm{b}}$ \\
Survival rate (\%) & $93.3 \pm 3.85$ & $100 \pm 0$ & $100 \pm 0$ & $96.03 \pm 0.33$ \\
\hline
\end{tabular}

Mean the same letter in the same row is not significantly different at $\mathrm{p} \leq 0.05$.

Table (3): Feed intake, Feed Conversion Ratio (FCR), Protein Efficiency Ratio (PER), Apparent Protein Utilization (APU) and Energy Utilization (EU) of Nile tilapia fed diets containing different levels of Artimizia extract.

\begin{tabular}{ccccc}
\hline \multirow{2}{*}{ Items } & Control & \multicolumn{2}{c}{ Artimizia extract \% in the diets } \\
\cline { 3 - 5 } & $\mathbf{0 \%}$ & $\mathbf{0 . 5 \%}$ & $\mathbf{1 \%}$ & $\mathbf{1 . 5 \%}$ \\
\hline Feed intake (gm/fish) & $34.1 \pm 0.34^{\mathrm{c}}$ & $39.74^{\mathrm{a}} \pm 0.22$ & $38.75^{\mathrm{a}} \pm 0.36$ & $37.29^{\mathrm{b}} \pm 0.52$ \\
FCR & $2.02^{\mathrm{a}} \pm 0.05$ & $1.63^{\mathrm{b}} \pm 0.07$ & $1.72^{\mathrm{b}} \pm 0.06$ & $1.86^{\mathrm{a}}{ }^{\mathrm{b}} \pm 0.04$ \\
PER & $1.76^{\mathrm{c}} \pm 0.05$ & $2.18^{\mathrm{a}} \pm 0.08$ & $2.03^{\mathrm{ab}} \pm 0.05$ & $1.84^{\mathrm{b}} \pm 0.04$ \\
APU \% & $27.30^{\mathrm{c}} \pm 0.28$ & $35.72^{\mathrm{a}} \pm 0.2$ & $33.08^{\mathrm{b}} \pm 0.32$ & $31.4 \pm 0.45^{\mathrm{bc}}$ \\
EU \% & $16.55 \pm 0.17^{\mathrm{c}}$ & $21.8^{\mathrm{a}} \pm 0.11$ & $19.63^{\mathrm{b}} \pm 0.22$ & $19.43^{\mathrm{b}} \pm 0.21$ \\
\hline
\end{tabular}


Table (4): Effect of artimizia extract supplementation with body composition and chemical analysis on dry matter basis (mean \pm SE) of Nile tilapia fed diets containing different levels of Artimizia extract.

\begin{tabular}{ccccc}
\hline \multirow{2}{*}{ Items } & Control & \multicolumn{2}{c}{ Artimizia extract \% in the diets } \\
\cline { 3 - 5 } & $\mathbf{0 \%}$ & $\mathbf{0 . 5 \%}$ & $\mathbf{1 \%}$ & $\mathbf{1 . 5 \%}$ \\
\hline Moisture \% & $74.64 \pm 0.68$ & $73.84 \pm 0.46$ & $73.75 \pm 0.27$ & $73.77 \pm 0.14$ \\
Crude protein \% & $60 \pm 0.06$ & $60.68 \pm 0.39$ & $60.59 \pm 0.37$ & $60.79 \pm 0.32$ \\
Ether extract \% & $19.72 \pm 0.22$ & $19.97 \pm 0.49$ & $19.67 \pm 0.18$ & $19.79 \pm 0.36$ \\
Ash \% & $19.81 \pm 0.31$ & $19.31 \pm 0.5$ & $19.11 \pm 0.61$ & $19.24 \pm 0.55$ \\
\hline
\end{tabular}

Table (5): Hematological parameters of fingerlings Nile tilapia (O. niloticus)] fed diets containing different levels of Artimizia.

\begin{tabular}{ccccc}
\hline \multirow{2}{*}{ Items } & Control & \multicolumn{3}{c}{ Artimizia \% in the diet } \\
\cline { 3 - 5 } & $\mathbf{0 \%}$ & $\mathbf{0 . 5 \%}$ & $\mathbf{1 \%}$ & $\mathbf{1 . 5 \%}$ \\
\hline Hb & $4.25^{\mathrm{d}} \pm 0.14$ & $4.5^{\mathrm{c}} \pm 0.15$ & $4.72^{\mathrm{b}} \pm 0.17$ & $5.11^{\mathrm{a}} \pm 0.13$ \\
RBCs & $1.43^{\mathrm{d}} \pm 0.02$ & $1.53^{\mathrm{c}} \pm 0.04$ & $1.74^{\mathrm{b}} \pm 0.04$ & $1.85^{\mathrm{a}} \pm 0.04$ \\
PCV & $14.02^{\mathrm{d}} \pm 0.41$ & $15.13^{\mathrm{c}} \pm 0.52$ & $16.83^{\mathrm{b}} \pm 0.62$ & $18.22^{\mathrm{a}} \pm 0.62$ \\
\hline
\end{tabular}

The means with the same letters are not significant in the same column $(\mathrm{p}>0.05)$. 
supplemented with Artimizia at rate of $0.5,1$ and $1.5 \%$, we showed that the extract had positive effect on growth performance specially with $0.5 \%$ of the extract. And also El-Saidy and Gaber (1997) reported that dried garlic meal can be used in the diets of Nile tilapia fingerlings at a level of $4 \%$ for increasing fish growth. And disagree with Abou Zeid (1998) who demonstrated that addition of different types of medicinal plant in diet of Nile tilapia had no significant effect on growth performance.

Nile tilapia fingerlings fed diets contained $0.5 \%$ artimizia extract exhibited the highest Feed intake (FI) (39.74 gm/fish), while the lowest FI was observed with control group (34.1 gm/fish). There were significant differences $(\mathrm{p}<0.05)$ in Feed Intake $(\mathrm{FI})$, Table (3). The best Feed Conversion Ratio (FCR) was observed with $0.5 \%$ artimizia extract (1.63), while fish fed the control diet showed worse FCR (2.20). the results showed that PER, APU and Eu improved with supplemented diet with different levels of Artimizia extract in Nile tilapia. The highest values of PER, APU and EU (2.18, 35.72 and 21.8 respectively) were obtained with diet contained Artimizia extract as compared to the control diet (1.76, 27.3 and 16.55 respectively). Sakar (2003) reported that higher significant differences were found in final weight, weight gain, weight gain \%, and SGR of fish fed different liens of dried Marjoram leaves and dried Basil leaves than control group, Also Abdel Wahab et al., (2007) reported that Nile tilapia fed diet containing $0.5 \%$ cinnamon showed better growth performance in general compard to other diets. Abdel Zaher et al., (2009) found that feed intake, FER, PER, APU and EU increased significantly, while decreased significantly in diet containing $1 \%$ dried fenugreek seeds while FCR increased significantly for control diet. But, these results agreed with our result.

\section{Effect of Artimizia extract supplementation on body fish composition:}

Data in table (4) show the whole body composition of Nile tilapia fingerlings at the end of the feeding experiment with dite suppleminted with artimizia. No significant difference $(p>0.05)$ was observed in whole body composition (moisture, protein, lipids, and ash contents) for Nile tilapia fed diets containing different levels of Artimizia extract. Moisture content has no significant difference due 
to supplementation diets with Artimizia extract and its range was $73.75-73.84 \%$. Protein content, fat content and ash content range were 60-60.79\%, 19.67-19.97\% and 19.11-19.81\% respectively.

Proximate chemical composition of fish at start of this study was $75.22 \pm 0.3 \%$ moisture; $59.04 \pm 0.82 \%$ protein; $18.11 \pm 0.76 \%$ lipid and $21.42 \pm 0.57 \%$ rash.

\section{Hematological indices of the growing fish:}

Data in table (5) show that Hemoglobin $(\mathrm{Hb})$, erythrocyte count (RBCs) and haematocrit (PCV) in the blood of tilapia (Oreochromis niloticus) increase with increasing Artimizia levels. It is noticed that fish-fed diets contining 1.5\% Artimizia exbhiited higher values of RBCs (1.85 UL), Hb (5.11 gm/L and PCV (18.22\%) than the control diets $(1.43,4.25$ and 14.02 , respectively).

\section{Serum biochemical parameters:}

\section{Total protein, albumin, and globulin values:}

the result show Total protein, albumin, and globulin values which increased significantly $(\mathrm{p} \leq 0.05)$ with artimizia extract supplementation and the highest values were obtained at $0.5 \%$ of the diet. The lowest value was obtained at the control diet. Artimizia extract supplementation insignificantly affected the Albumin/Globulin (A/G) ratio

\section{ALT and AST values:}

the result show that ALT and AST values decreased with the increased supplementation by artimizia extract, the highest values were obtained at the control diet

\section{Determination of urea, creatinine and glucose in fish:}

Data The results in table (6) obtained from fed Nile tilapia by Artimizia in serum biochemical parameters as showed that urea and creatinine decrease significantly $(\mathrm{p}<0.05)$ with increasing levels of artimizia. There are decreases in glucose fed diet $1.5 \%(60.21)$ and $1 \%(62.43)$ respectively than in control diet (73).

Hematological studies agreement with El-Mallah (2003) who showed that blood plasma parameters showed an improvement in 
total protein, albumin and globulin and decrease in liver enzymes in addition of some medicinal plants all treatment groups. Also Ali et al., (2005) indicated that total plasma protein and haemoglobin concentrations were significantly higher $(\mathrm{p}<0.05)$ in the blood of lambs fed treated rations (G2 and G3) than those fed control ration. Furthermore, albumin, globulin, and urea concentrations were slightly increased. Meanwhile, the enzyme activities of AST and ALT were slightly decreased by increasing the chamomile level in treated rations. Also agreement with Abdel Azeem (2006) showed that plasma total protein, albumin, and globulin were increased, while AST and ALT decreased for groups fed with Fenugreek (FK) and Fennel (FL) compared to those fed the control diet.

\section{Challenge test:}

Data in table (7) show that the results of challenge test by intraperitoneal injection with Aeromonas hydrophila in Nile tilapia fed by Artimizia. the mortality percent was higher in control group (89\%) than other groups of fish fed Artimizia supplemented dite. The mortality percent in groups fed diet containing different levels of Artimizia was 22, 0 and 0 for $0.5,1$ and $1.5 \%$ respectively. So, the Artimizia increased resistant of fish against Aeromonas hydrophila in fresh water. Also, the use of Artimizia, the dose (1\%) was enough.

This result agreement with Ahmed et al., (2009) who indicated that fish was challenged against $\boldsymbol{A}$. hydrophilia for 10 days and the highest fish mortality was recorded in the first day and decrease by time up to $4^{\text {th }}$ day for each treatment of different levels of cinnamon (Cinnamomum zeylanicum, NEES) except the group fed 0.4 organism that had no fish mortality. No mortality was observed after the $4^{\text {th }}$ day at all treatments. The highest overall mortality was observed at control 80\%, also Sahu et al., (2007) studied dietary dosage of garlic on the immunoresponse and disease resistance against infection by $\boldsymbol{A}$. hydrophilia and some medical plants incorporated into the diet and every 20 day different biochemical and hematological parameters were evaluated, and after 60-day fish were challenged by A.hydrophilia and mortality was recorded up to day 10 postchallenge. Survival decrease in control group 57\% up to day 10 after infection and increase in treatment group and finally indicated 
Table (6): Biochemical parameters, blood urea $(\mathrm{mg} / \mathrm{dl})$, serum creatinine $(\mathrm{mg} / \mathrm{dl})$ of fingerlings Nile tilapia $(O$. niloticus) fed diets containing different levels of Artimizia.

\begin{tabular}{ccccc}
\hline \multirow{2}{*}{ Items } & Control & \multicolumn{3}{c}{ Artimizia levels \% in the diet } \\
\cline { 3 - 5 } & $\mathbf{0 \%}$ & $\mathbf{0 . 5 \%}$ & $\mathbf{1 \%}$ & $\mathbf{1 . 5 \%}$ \\
\hline $\begin{array}{c}\text { Urea } \\
\mathbf{( m g / d l )}\end{array}$ & $17.21 \pm 0.09^{\mathrm{a}}$ & $15.92 \pm 0.06^{\mathrm{b}}$ & $14.72 \pm 0.05^{\mathrm{c}}$ & $13.81 \pm 0.07^{\mathrm{d}}$ \\
$\begin{array}{c}\text { Creatinine } \\
\mathbf{( m g / d l )}\end{array}$ & $0.48 \pm 0.02^{\mathrm{a}}$ & $0.43 \pm 0.02^{\mathrm{b}}$ & $0.4 \pm 0.01^{\mathrm{c}}$ & $0.36 \pm 0.01^{\mathrm{d}}$ \\
$\begin{array}{c}\text { Glucose } \\
(\mathbf{m g} / \mathbf{d l})\end{array}$ & $73 \pm 2.51^{\mathrm{a}}$ & $74.36 \pm 3.62^{\mathrm{a}}$ & $62.43 \pm 3.15^{\mathrm{b}}$ & $60.12 \pm 2.42^{\mathrm{b}}$ \\
\hline
\end{tabular}

The means with the same letters are not significant in the same column $(\mathrm{p}>0.05)$.

Table (7): Mortality rate (\%) of fingerlings Nile tilapia $O$. niloticus fed diets containing different levels of Artimizia for 90 days and challenged by A. hydrophila for 10 days.

\begin{tabular}{ccccc}
\hline Items & Control & \multicolumn{3}{c}{ Artimizia levels \% in the diet } \\
\cline { 3 - 5 } & $\mathbf{0 \%}$ & $\mathbf{0 . 5 \%}$ & $\mathbf{1 \%}$ & $\mathbf{1 . 5 \%}$ \\
\hline Number of injected fish & 10 & 10 & 10 & 10 \\
Bacteria dose (5 x 10 $\mathbf{5}$ CFU) & $0.2 \mathrm{ml}$ & $0.2 \mathrm{ml}$ & $0.2 \mathrm{ml}$ & 0.2 \\
$\begin{array}{c}\text { Injection route } \\
\text { Mortality rate (\%) after 10 }\end{array}$ & $\mathrm{I} / \mathrm{P}$ & $\mathrm{I} / \mathrm{P}$ & $\mathrm{I} / \mathrm{P}$ & $\mathrm{I} / \mathrm{P}$ \\
days of injection & 89 & 22 & 0 & 0 \\
\hline
\end{tabular}


that medical plant stimulate the immunity and make L-rohita more resistant to infection by $\boldsymbol{A}$. hydrophilia.

Efficiency of Artimizia extract against the pathogenic $A$. hydrophilia.

\section{Among Orechromis niloticus:}

Table (8) showed that the intrapretonial inoculation (I/P) of $(5 \mathrm{x}$ $\left.10^{5}\right)$ cells/ml of $\boldsymbol{A}$. hydrophila caused mortality (90\%) among Orechromis niloticus, while the treated Orechromis niloticus with Artimizia had mortality (40\%).

Table (8): Efficinecy of Artimizia extract against the pathogenic $A$. hydrophila among Orechromis niloticus.

\begin{tabular}{ccccc}
\hline Parameters & $\begin{array}{c}\text { (Bact.) } \\
\text { A. } \\
\text { hydrophila }\end{array}$ & $\begin{array}{c}\text { Artimizia } \\
\text { extract } \\
\text { (Ex) }\end{array}$ & Bact. + Ex. & $\begin{array}{c}\text { Ctonr } \\
\text { ol }\end{array}$ \\
\hline $\begin{array}{c}\text { No. of } \\
\text { examined fish }\end{array}$ & 20 & 20 & 20 & 20 \\
Bacteria dose & $\begin{array}{c}5 \times 10^{5} \\
\text { cells /ml }\end{array}$ & $0.5 \mathrm{ml}$ & $\begin{array}{c}0.2 \mathrm{ml} \text { from } \\
\text { bact. + 0.5ml } \\
\text { from Ex }\end{array}$ & $\begin{array}{c}0.2 \mathrm{ml} \\
\text { saline }\end{array}$ \\
$\begin{array}{c}\text { Route of } \\
\text { injection }\end{array}$ & $\mathrm{I} / \mathrm{P}$ & $\mathrm{I} / \mathrm{P}$ & $\mathrm{I} / \mathrm{P}$ & $\mathrm{I} / \mathrm{P}$ \\
Mortality rate & $90 \%$ & 0.0 & $40 \%$ & 0.0 \\
\hline Bact. = Bacteria & Ex. = Extract & $\mathrm{I} / \mathrm{P}=$ Intrapretonial injection &
\end{tabular}

\section{References}

Abdel Azeem F. (2006): Effect of using fenugreek and fennel seeds as natural feed additives on performance of broiler chicks. Egyptian J. Nutrition and Feeds; 9(2): 277-297.

Abdel Zaher A.M.M., Ahmad M.H. and Mousallamy A. (2009): Effect of using dried fenugreek seeds as natural feed additives on growth performance fed utilization whole-body composition and entropathogenic Aeromonas hydrophila-challenge of monsex Nile tilapia O. Niloticus (L) Fingerlings. Australian Journal of Basic and Applied Science; 3(2): 1234-1245. 
Abou-Zeid, R.M. (1998): Evaluation of some medicinal plants as a feed additive in diets of Nile tilapia (Oreochromis niloticus). MSc Fac of Agric, El-Fayoum, Cairo University.

Ahmad M.H., El-Mesallamy A.M., Samir F. and Zahran Z. (2009): Effect of different levels of cinnamon (Cinnamomum zeylanicum, NEES) on growth performance, feed utilization, while-body composition and enteropathogenic Aeromonas hydrophila - chlallenge of all male Nile tilapia Oerochromis niloticus L. Fingerlings. Egypt. J. Appl. Sci.; 24(5A): 1-18.

Ali M.F., Saleh M.S., Eweedah N.M. and Mahmoud S.A. (2005): Effect of using chamomile (Mtricaria chamomilla) flowers as feed additives on performance of growth lambs under deser farming systems. Egyptian. J. Nutrition and Feeds; 8(2): 127-137.

AOAC,( 1990) Official Methods of Analysis, 13th edn. Association of Official Analytical Chemists, Washington DC, USA, 1094 pp.

Boyd CE (1990): Water Quality in Ponds for Aquaculture. Birmingham Publishing Co., Birmingham, Alabama, USA.

Christen, P., Veuthey, J. L..(2001): New trends in extraction, identification and quantification of artemisinin and its derivates. Current medical chemistry, 8, p. 1827-1839.

Dytham C (1999): Choosing and using statistics: A biologist's Guide. Blacwell Science LTd, London, UK; 147.

El-Mallah GM (2003): Response of growign Turkey to some medicinal plants as natural growth promoters. J. Agric. Sci. Mansoura Univ.; 28(11): 6621-6631.

El-Saidy D.M.S.D. (1999): Effect of different levels of dried onion meal supplemented to the diets on growth, feed utilization and body composition of Nile tilkapia. Oreochromis niloticus fingerlings. Monofiya J. Agri. Res.; 24(2): 481-492.

El-Saidy and Gaber (1997): Effect of different levels of dried garlic meal supplemented to the diets on growth performances, survival and body composition of Nile tilapia, Orochromis niloticus fingerlings. Ann. Agri. Sci. Moshtohor; 35(3): 1197-1209. 
Froese, Rainer and Pauly, Daniel, (2015): "Oreochromis niloticus" in Fish Base. November version.

Ibrahim M.R., Abdel Latif M.S. and EL-Yamany A.T. (1998): Effect of dding some natural growth promoters to broiler chick's diets on growth performance, digestibility and some metabolic functions. J. Agric. Sci. Mansoura Univ.; 32(3): 1029.

Jauncey, K., Ross, B., (1982) A Guide to Tilapia Feeds and Feeding. Institute of Aquaculture, University of Stirling, Stirling, Scotland, $111 \mathrm{pp}$.

Jun WJ, Han BK, Yu KW, Kim MS, Chang IS, Kim HY and Cho HY (2001): Antioxidant effects of Organum majorana L. on superoxide anion radicals. Food Chem; 75: 439.

Mahdy GB (2005): Medicinal plants for the prevention of bacterial plants as sou proteins; 11(19): 2405-2427.

NRC (1994) : Nutrient requirements of Poulty $9^{\text {th }}$ Rev. Ed. National Academy Press, Washington, DC, USA.

Papageorgiou G, Botsoglou N and Govaris A (2003): Effect of dietary oregano oil and $\alpha$-tocophery acetate supplementation on iron-induced lipid oxidation of turkey breast, thigh, liver and heart tissues. J. Anim. Physiol. Anim. Nutr.; 87: 324.

Sahu, s.,B.K.Das,B.K .mishra,J.pradhan and N.sarangi.(2007). Effect of Allium sativum on the immunity and survival of Labeo rohita infected with Aeromonas hydrophila. J. Appl. Ichthyol., 23:80-86.

Sakr S.E. (2003): Studies on feeding attractant for fish. M.Sc. Thesis, Faculty of Environmental Agric. Sci., Suez Canal University, Egypt.

Schäperclacus W., Kulow H. and schreckenback K. (1992). Fish Disease ,I.A. A. Balkema / Rotterdam. the Netherlands.

Shalaby S.M.M., Abdsel Moneem A.L. and EL-Dakar A.Y. (2003): Enhancement of growth performance, feed and nutrient utilization of Nile tilapia, Oreochromis niloticus, using locorice rotos (Erksous) as a feed attractive. J. Egypt. Acad. Soc. Environ. Develop. (B-Aquaculture); 4(2): 119-142. 
Surh (2002): Y.J. Antitumer promoting potential of selected spice ingrediants with antioxidative and anti infilammatory activites :short review,food and Chemical Toxicology 40,1091,summary plus Full Text + links PDF(168 K)

Vagi E, Rapavi E, Hadolin M, Vasarhelyne Peredi K, Balaz A, Blazovic A and Simandi B (2005): Phenolic triterpenoid antioxidants from Origanum majorana L. herb and extracts obtained with different solvents. J. Agric. Fo 
تأثير استخدام مستخلص نبات الثيح البلاى على أداء النمو وكوقاية و علاج لأسماك البلطى النيلى ضد بكتيريا الايروموناس هيلئروفيلا.

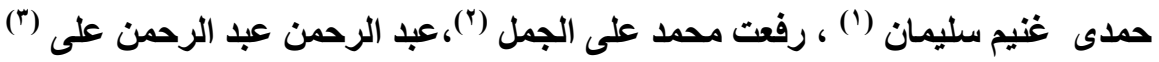
ا ـ قسم النبات و الميكروبيولوجى ـ كلية العلوم - جامعة الاز هر ـ مصر

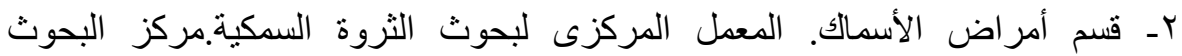

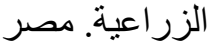
r - مستشفى ابوحماد - وزارة الصحة - مصر الملخص العربى مصنى

أجريت هذه الدراسة بقسم صحة الاسماك ورعايتها بالمعمل المركزى لبحوث الثروة الثرة

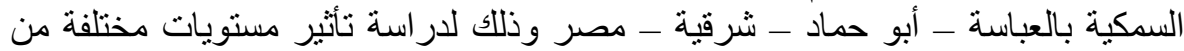

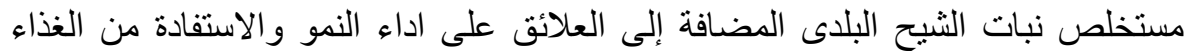

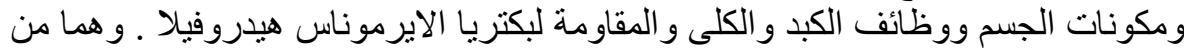

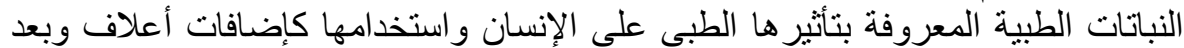

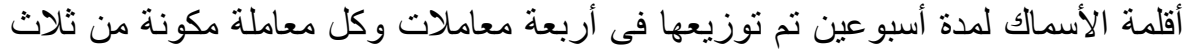

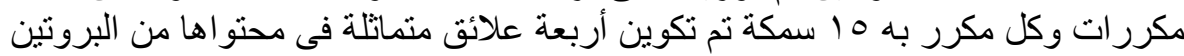

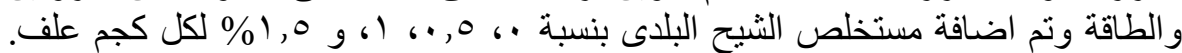

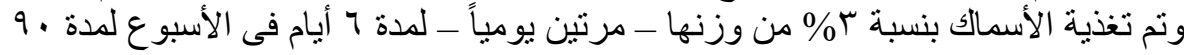

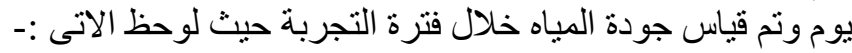

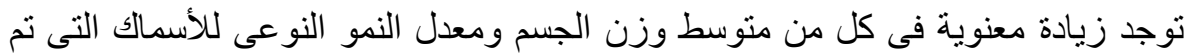

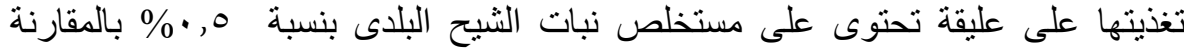

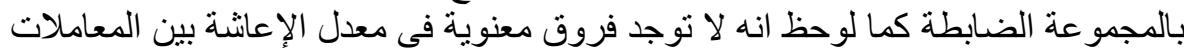

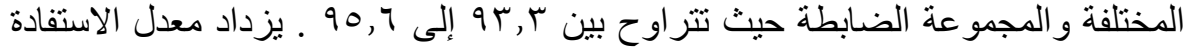

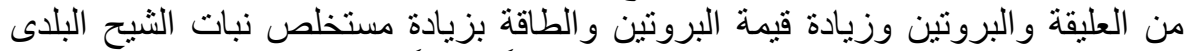

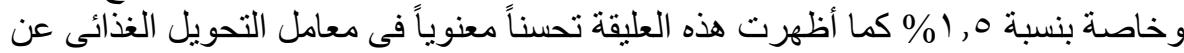

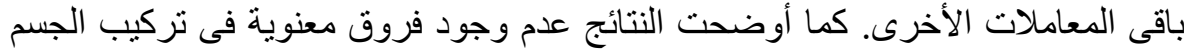

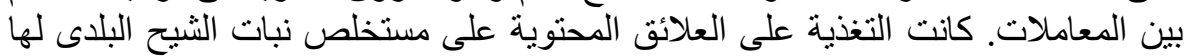

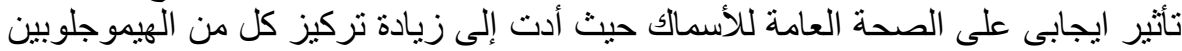

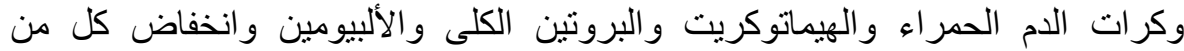

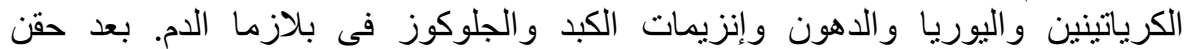

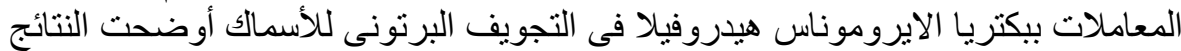

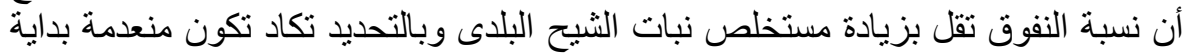

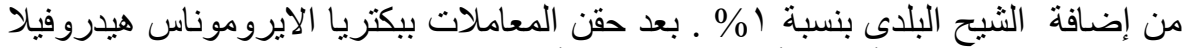

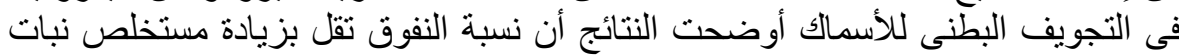

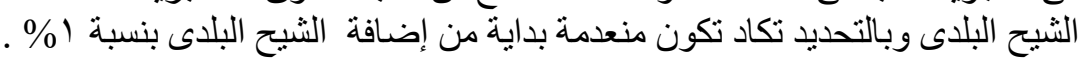

